\title{
Mycorrhizal Inoculation Effect on the Forage Cowpea Biomass Production in Burkina Faso
}

\author{
Hadou Haro1* ${ }^{*}$ Kadidia Semdé1, Kadidiata Bahadio², Souleymane Ganaba3 \\ ${ }^{1}$ Laboratoire de Microbiologie Forestière, Département Environnement et Forêts/Institut de l'Environnement et de Recherches \\ Agricoles (DEF/INERA), Ouagadougou, Burkina Faso \\ ${ }^{2}$ Institut du Développement Rural (IDR), Université Nazi Boni, Bobo-Dioulasso, Burkina Faso \\ ${ }^{3}$ Département Environnement et Forêts/Institut de l'Environnement et de Recherches Agricoles (DEF/INERA), Ouagadougou, \\ Burkina Faso \\ Email: `harohadou@yahoo.fr
}

How to cite this paper: Haro, H., Semdé, K., Bahadio, K. and Ganaba S. (2020) Mycorrhizal Inoculation Effect on the Forage Cowpea Biomass Production in Burkina Faso. American Journal of Plant Sciences, 11, 1714-1722.

https://doi.org/10.4236/ajps.2020.1111123

Received: July 13, 2020

Accepted: November 15, 2020

Published: November 18, 2020

Copyright (c) 2020 by author(s) and Scientific Research Publishing Inc. This work is licensed under the Creative Commons Attribution International License (CC BY 4.0).

http://creativecommons.org/licenses/by/4.0/

cc) Open Access

\begin{abstract}
In Burkina Faso, breeding occupies an important place in the country's economy, but is based essentially on the exploitation of the natural resources (pasture) which remains limited in extent due to the extension of land cultivated by agricultural practices extensive. Food is one of the most important limiting factors in animal production, hence the need to develop mechanisms to improve the production of food resources. This study is a contribution to fodder production improvement. In this study, cowpea was grown in a greenhouse for 60 days and inoculated with two inocula of arbuscular mycorrhizal fungi. The growth parameters were measured at 30 and 60 days after sowing. Shoot, root and total biomass were evaluated 60 days after sowing. The results show Yac 2 mix inoculum improves height growth (95.5\%), height relative growth rate (525\%), collar diameter (138\%), collar diameter relative growth rate $(328.57 \%)$, shoot biomass $(396.3 \%)$, root biomass by (205.66\%), total biomass by (320\%), total nitrogen of aerial parts $(92.39 \%)$ and total phosphorus of aerial parts (143.48\%) compared to control. Yac 2 mix appears the most effective of all inoculum used in this study.
\end{abstract}

\section{Keywords}

Forage Cowpea, Mycorrhizal Inoculation, Arbuscular Mycorrhizal Fungi, Burkina Faso

\section{Introduction}

In Burkina Faso, breeding is the third export product after gold and cotton. In a country with an agro-pastoral vocation, breeding occupies more than $80 \%$ of 
households in rural areas and constitutes the second productive sector in rural areas. It contributes $18 \%$ to gross domestic product (GDP) and constitutes a source of income for around $80 \%$ of the population [1]. However, an extensive type, this breeding is based essentially on natural resource exploitation. The major part of the food resources comes from natural pastures which, even if they are capable of improvement, remain nevertheless limited in extent due to the extension of the cultivated lands by extensive agricultural practices. In this country, the rainy season corresponding to the abundance of natural pastures remains very short. It varies from 3 months in the Sahelian zone to 5 months in the Sudanian zone [2]. Lack of fodder during the dry season is a major constraint on animal production, hence the need to find mechanisms to produce the quantity and quality of fodder. So, forage cowpeas could help improve forage production. However, in Burkina Faso, demographic pressure and the growing need to satisfy agricultural products are causing more and more intensive exploitation of natural resources (land, pastures). This overexploitation exceeds the capacity of the land which is characterized by soils lacking in nutrients, specifically nitrogen and assimilable phosphorus [3] with a low organic matter content, which shows the need to use fertilizers to ensure satisfactory and stable agricultural production. However, the use of chemical fertilizers has shown its limits due to pollution of soil and water, the appearance of pathogens resistant to pesticides, the high costs of pesticides, risks to the health of farmers and even embrittlement ecosystems [4]. Therefore, maintaining the productivity of crops by replacing the use of chemical fertilizers by mobilizing biological processes is at the heart of the challenges of current research.

However, cowpea [Vigna unguiculata (L.) Walp.] is a legume capable of associating with arbuscular mycorrhizal fungi (AMF) capable of improving their growth and production even when these plants grow on soils poor in mineral elements [5] [6] [7]. The exploitation of this symbiosis would be a possibility to improve the growth and production of cowpeas. Thus, this study was initiated with the aim of helping to improve its fodder production by mycorrhizal inoculation with Burkina Faso native arbuscular mycorrhizal fungi (AMF).

\section{Materials and Methods}

\subsection{Plant and Fungal Materials}

Seeds of Vigna unguiculata were used. The cowpea seeds were superficially disinfected by soaking in $96 \%$ ethanol for $3 \mathrm{~min}$, rinsed thoroughly with sterile distilled water then disinfected in calcium hypochlorite solution $\left(\mathrm{CaCl}_{2} \mathrm{O}_{2}\right.$ at $3.3 \%$, $\mathrm{w} / \mathrm{v}$ ) for $3 \mathrm{~min}$ and finally rinsed thoroughly with sterile distilled water before sowing. These seeds were then sown at a rate of 4 per pot.

Fungal material was composed of four local AMF isolated from the rhizosphere of cowpeas grown in Burkina Faso [8]: Yac 2 mix (Scutellospora sp., Gigaspora sp., Glomus sp.), Entrophospora sp., Gigaspora sp. and Glomus sp. These inocula were chosen for their performance in improving the KVX 
396-4-5-2D cowpea variety growth of from previous studies [8]. The inocula were obtained by multiplication of cowpea rhizosphere indigenous arbuscular mycorrhizal fungi [9]. Mycorrhizal inoculum production consisted of multiplying local AMF. Thus, maize (Zea mays) is grown in greenhouse in 4 liter pots containing $4 \mathrm{~kg}$ of sterile soil and inoculated with local AMF. The control pots also received $4 \mathrm{~kg}$ of sterile soil each, but were not inoculated. Each treatment is repeated 3 times and the test lasted 6 months. The inoculum is composed of a mixture of spores, mycorrhized roots fragments and soil. This inoculum is stored at $4^{\circ} \mathrm{C}$.

\subsection{Culture Substrate}

The culture substrate was a sterilized soil of Ouagadougou [clay: 3.92\%; total silt: 5.88\%; total sand: $90.2 \%$; total organic matter: $0.331 \%$; total carbon: $0.192 \%$; total nitrogen: $0.016 \%$; C/N: 12; total phosphorus: $172.52 \mathrm{ppm}$; available phosphorus: $1.74 \mathrm{ppm} ; \mathrm{pH} \mathrm{H}_{2} \mathrm{O}(\mathrm{w} / \mathrm{v}: 1 / 2.5)$, 6.44]. Culture substrate was homogenized, sieved with a $2 \mathrm{~mm}$ sieve and sterilized at $121^{\circ} \mathrm{C}$ for $1 \mathrm{~h}$. It was this same culture substrate that was used throughout the study.

\subsection{Test Implementation}

The test consisted of growing cowpeas under greenhouse conditions (average temperature: $28^{\circ} \mathrm{C}-30^{\circ} \mathrm{C}$; day length: $12 \mathrm{~h}$ ) in 2 liter pots containing $2 \mathrm{~kg}$ of sterile culture substrate. The cowpea was sown at the rate of 4 seeds per pot and a wedge was carried out two weeks after the plants emergence to leave only one plant per pot. The inoculation was carried out at sowing time with $10 \mathrm{~g}$ of inocula (as described by Haro et al. [6]) per pot for each inoculated treatment. Control pots were not inoculated. This device was composed of 5 treatments [four inoculated treatments (Yac 2 mix, Entrophospora sp., Gigaspora sp. and Glomus sp.) and one control] with 10 replicates per treatment has been retained. The experimental design used was a simple randomization complete block design. This experiment lasted 60 days (flowering/fruiting stage).

To determine how inoculation affected cowpeas plant development, grow parameters, shoot, root and total biomass then aboveground partschemical characteristics were measured.

\subsection{Grow Parameters Measurement}

To estimate the effect of mycorrhizal inoculation on the cowpea, the height, the collar diameter, height relative growth rate and collar diameter relative growth rate were calculated at the $30^{\text {th }}$ and at the $60^{\text {th }}$ day after sowing. The height relative growth rate $(R G R h)$ was calculated according to the formula (a) [10] [11] [12]:

$$
R G R h=\frac{\ln \left(H_{2}\right)-\ln \left(H_{1}\right)}{T_{2}-T_{1}}
$$

with $H$ : height; $T$ : time; ${ }_{1}$ : initial, ${ }_{2}$ : final. 
The collar diameter was measured using a caliper at the separation zone between the root system and the aerial part of 30 and 60 days after sowing. The collar diameter relative growth rate $(R G R D c)$ was calculated according to the formula (b) [10] [11] [12]:

$$
R G R D c=\frac{\ln \left(D c_{2}\right)-\ln \left(D c_{1}\right)}{T_{2}-T_{1}}
$$

with $D c$. collar diameter; $T$ : time; ${ }_{1}$ : initial; ${ }_{2}$ : final.

\subsection{Shoot, Root and Total Biomass Measurement}

At 60 days after sowing, each plant was carefully removed to recover the aerial part and all roots of the plants. These all parts were dried in $70^{\circ} \mathrm{C}$ oven for 72 hours for shoot, root and total biomass measurement. After the biomass measurement, the roots were used for the mycorrhizal infection study. The chemical analysis (total nitrogen and total phosphorus) of cowpea aboveground parts was carried out by Bureau National des Sols (BUNASOLS) in Burkina Faso.

\subsection{Staining for Mycorrhizal Colonization}

About $10 \mathrm{~g}$ of roots from each treatment was thoroughly washed and placed in falcon tubes then cleared using $10 \% \mathrm{KOH}$. They were heated in $90^{\circ} \mathrm{C}$ water bath for one hour. The roots were washed with tap water. Staining was then done by adding $0.05 \%$ trypan blue in lactic acid and heating in $90^{\circ} \mathrm{C}$ water bath for 30 minutes as described by Phillips, Hayman [13] and observation was done under the microscope (magnification $=10 \times$ ). The mycorrhizal frequency and intensity were estimated by Trouvelot et al. [14] method.

\subsection{Statistical Analysis}

Data were statistically analyzed using a one-way analysis of variance (ANOVA) with XLSTAT 2019 statistical software and the means were compared using the Newman-Keuls test $(\mathrm{p}<5 \%)$.

\section{Results}

\subsection{Mycorrhization Frequency and Intensity Evaluation}

The frequency and intensity of mycorrhization of cowpeas inoculated with the different local arbuscular mycorrhizal fungi (AMF) strain results (Table 1) show that mycorrhization was variable from inocula. The highest values are obtained with the Yac 2 mix inoculum both the frequency (98\%) and the intensity of mycorrhization $(55.05 \%)$. Statistical analyzes show significant differences $(\mathrm{p}<0.05)$ between the different treatments and the control treatment roots are not mycorrhizal.

\subsection{Efficiency of Native AMF Strains}

Table 2 and Table 3 present the values of the height, as described by the height 
Table 1. Cowpea mycorrhizal frequency and intensity 60 days after sowing inoculated with 2 mycorrhizal inocula (Yac 2 mix and Glomus sp.).

\begin{tabular}{ccc}
\hline Treatments & Mycorrhizal Frequency (\%) & Mycorrhizal Intensity (\%) \\
\hline Yac 2 mix & $98 \pm 1.33^{\mathrm{a}}$ & $55.05 \pm 4.14^{\mathrm{a}}$ \\
Entrophospora sp. & $89 \pm 2.77^{\mathrm{a}}$ & $31.05 \pm 3.43^{\mathrm{b}}$ \\
Gigaspora sp. & $88 \pm 2.91^{\mathrm{a}}$ & $29.3 \pm 3.5^{\mathrm{b}}$ \\
Glomus sp. & $74 \pm 6.18^{\mathrm{b}}$ & $24.77 \pm 0.45^{\mathrm{b}}$ \\
Control & $0^{\mathrm{c}}$ & $0^{\mathrm{c}}$ \\
Significancelevel & $<0.0001$ & $<0.0001$ \\
\hline
\end{tabular}

For the same column, data followed by the same letters are not significantly different according to the Newman-Keuls test $(\mathrm{p}>0.05)$. Standard error of the mean $(\mathrm{n}=10)$.

Table 2. Plant height, the collar diameter, the height relative growth rate and the collar diameter relative growth rate of cowpea inoculated with 2 mycorrhizal inocula (Yac 2 mix and Glomus sp.).

\begin{tabular}{ccccccc}
\hline Treatments & Height 1 $(\mathrm{cm})$ & Height 2 $(\mathrm{cm})$ & $\begin{array}{c}\text { RGRh } \\
(\mathrm{cm} / \text { day.cm })\end{array}$ & $\begin{array}{c}\text { collar diameter 1 } \\
(\mathrm{mm})\end{array}$ & $\begin{array}{c}\text { Collar diameter 2 } \\
(\mathrm{mm})\end{array}$ & $\begin{array}{c}\text { RGRDc } \\
(\mathrm{cm} / \text { day.cm })\end{array}$ \\
\hline Yac 2 mix & $18.9 \pm 1.71^{\mathrm{a}}$ & $40 \pm 1.58^{\mathrm{a}}$ & $0.025 \pm 0.001^{\mathrm{a}}$ & $2.9 \pm 0.22^{\mathrm{a}}$ & $7.14 \pm 0.13^{\mathrm{a}}$ & $0.03 \pm 0.001^{\mathrm{a}}$ \\
Entrophospora sp. & $17.16 \pm 0.84^{\mathrm{a}}$ & $33.32 \pm 0.99^{\mathrm{b}}$ & $0.022 \pm 0.001^{\mathrm{a}}$ & $2.9 \pm 0.9^{\mathrm{a}}$ & $3.7 \pm 0.08^{\mathrm{c}}$ & $0.009 \pm 0.001^{\mathrm{b}}$ \\
Gigaspora sp. & $17.59 \pm 0.33^{\mathrm{a}}$ & $29.01 \pm 0.78^{\mathrm{c}}$ & $0.017 \pm 0.006^{\mathrm{b}}$ & $2.6 \pm 0.28^{\mathrm{a}}$ & $3.5 \pm 0.2^{\mathrm{c}}$ & $0.016 \pm 0.002^{\mathrm{b}}$ \\
Glomus sp. & $15.36 \pm 0.66^{\mathrm{a}}$ & $23.2 \pm 2.34^{\mathrm{d}}$ & $0.011 \pm 0.009^{\mathrm{c}}$ & $2.58 \pm 0.13^{\mathrm{a}}$ & $4.25 \pm 0.44^{\mathrm{b}}$ & $0.016 \pm 0.001^{\mathrm{b}}$ \\
Control & $17.9 \pm 1.46^{\mathrm{a}}$ & $20.46 \pm 1.89^{\mathrm{d}}$ & $0.004 \pm 0.004^{\mathrm{d}}$ & $2.42 \pm 0.11^{\mathrm{a}}$ & $3 \pm 0.13^{\mathrm{d}}$ & $0.007 \pm 0.001^{\mathrm{b}}$ \\
Significance level & NS & $<0.001$ & $<0.001$ & NS & $<0.001$ & $<0.001$ \\
\hline
\end{tabular}

For the same column, data followed by the same letters are not significantly different according to the Newman-Keuls test $(\mathrm{p}>0.05)$. Standard error of the mean $(\mathrm{n}=10)$. Height 1 and 2: height measured respectively at 30 and 60 days after sowing. Collar diameter 1 and 2: collar diameter measured respectively at 30 and 60 days after sowing. NS: not significant.

Table 3. Plant shoot, root and total biomass 60 days after the sowing of cowpea inoculated with 2 mycorrhizal inocula (Yac 2 mix and Glomus sp.).

\begin{tabular}{cccccc}
\hline Treatments & $\begin{array}{c}\text { Shoot biomass } \\
\text { (g per plant) }\end{array}$ & $\begin{array}{c}\text { Root biomass } \\
\text { (g per plant) }\end{array}$ & $\begin{array}{c}\text { Total biomass } \\
\text { (g per plant) }\end{array}$ & $\begin{array}{c}\text { Total nitrogen (N) } \\
(\%)\end{array}$ & $\begin{array}{c}\text { Total phosphorus } \\
(\mathrm{P}) \mathrm{g} \cdot \mathrm{kg}^{-1}\end{array}$ \\
\hline Yac 2 mix & $4.05 \pm 0.25^{\mathrm{a}}$ & $1.62 \pm 0.16^{\mathrm{a}}$ & $5.67 \pm 0.24^{\mathrm{a}}$ & $1.77 \pm 0.12^{\mathrm{a}}$ & $0.56 \pm 0.03^{\mathrm{a}}$ \\
Entrophospora sp. & $3.18 \pm 0.2^{\mathrm{b}}$ & $1.03 \pm 0.05^{\mathrm{b}}$ & $4.21 \pm 0.17^{\mathrm{b}}$ & $1.6 \pm 0.12^{\mathrm{ab}}$ & $0.4 \pm 0.02^{\mathrm{b}}$ \\
Gigaspora sp. & $3.4 \pm 0.13^{\mathrm{b}}$ & $1.09 \pm 0.04^{\mathrm{b}}$ & $4.49 \pm 0.14^{\mathrm{b}}$ & $1.39 \pm 0.07^{\mathrm{b}}$ & $0.34 \pm 0.04^{\mathrm{bc}}$ \\
Glomus sp. & $2.23 \pm 0.03^{\mathrm{c}}$ & $1.1 \pm 0.25^{\mathrm{b}}$ & $3.33 \pm 0.27^{\mathrm{c}}$ & $1.44 \pm 0.08^{\mathrm{b}}$ & $0.28 \pm 0.05^{\mathrm{cd}}$ \\
Control & $0.81 \pm 0.19^{\mathrm{d}}$ & $0.53 \pm 0.09^{\mathrm{c}}$ & $1.34 \pm 0.28^{\mathrm{d}}$ & $0.92 \pm 0.09^{\mathrm{c}}$ & $0.23 \pm 0.01^{\mathrm{d}}$ \\
Significance level & $<0.001$ & 0.004 & $<0.001$ & $<0.001$ & $<0.001$ \\
\hline
\end{tabular}

For the same column, data followed by the same letters are not significantly different according to the Newman-Keuls test $(\mathrm{p}>0.05)$. Standard error of the mean $(\mathrm{n}=10)$.

relative growth rate (RGRh), the collar diameter, the collar diameter relative growth rate (RGRDc), the shoot, root and total biomass then the mineral element content of the aerial parts of cowpeas.

For height, the results vary depending on the inoculum and the measurement period. At 30 days after sowing, statistical analyzes do not show any significant difference ( $p>0.5$ ) between the different treatments either the height or the col- 
lar diameter. Thus, for 60 days after sowing, statistical analysis showed significant differences $(\mathrm{p}<0.05)$ between the various treatments for all the parameters. The Yac 2 mix inoculum provides the highest values for height $(40 \mathrm{~cm})$, height relative growth rate $(0.025 \mathrm{~cm} /$ day.cm), collar diameter $(7.14 \mathrm{~mm})$, collar diameter relative growth rate $(0.03 \mathrm{~cm} /$ day.cm), shoot biomass $(4.02 \mathrm{~g})$, root biomass $(1.62 \mathrm{~g})$, total biomass $(5.64 \mathrm{~g})$, total nitrogen of aerial parts $(1.77 \%)$ and total phosphorus of aerial parts $\left(0.56 \mathrm{~g} \cdot \mathrm{kg}^{-1}\right)$ of cowpeas.

\section{Discussion}

The mycorrhizal infection results show that the cowpea roots are strongly mycorrhized by the mycorrhizal strains used. These results are in agreement with those of Haro et al. [5] who showed that cowpea was strongly mycorrhized. However, the mycorrhizal infection was absent on the control roots. This could be explained by the absence of any mycorrhizal contamination from the treatments. Similar results were obtained by Haro et al. [9]. The stimulation of growth parameters, biomass production and mineral elements content of cowpea between the different treatments and the control could be attributed to the AMF inoculation effect.

At 30 days after sowing, inoculation did not improve either the height or the collar diameter $(\mathrm{p}>0.5)$. This could be explained by the fact that the substrate used contains the necessary nutrients and directly accessible by the cowpeas roots proper nutrition. These results corroborate those of Haro et al. [9]. These authors have shown that since the symbiosis improves water and mineral nutrition, the plant will not find any need to form this symbiosis if the nutrients are available in the environment and directly accessible to the roots. However, with the plant evolution, the nutrients are gradually depleted in the soil and the roots can no longer meet the nutritional needs of the plant. Therefore, to fill this nutrient deficiency, the plant is forced to use the mycorrhizal symbiosis. Thus, for 60 days after sowing, significant differences $(p<0.05)$ appear between the different treatments for the height, the collar diameter, total nitrogen and total phosphorus of aerial parts, shoot, root and total biomass. The same is true for the height relative growth rate, collar diameter and collar diameter relative growth rate. Generally, all inocula used improved cowpea growth and biomass production. Also, apart from Glomus sp. inoculum which did not improve the phosphorus content of cowpea compared to the control, all inocula improved nitrogen and phosphorus content of cowpea aerial parts. These results could be explained by the effectiveness of the inocula used. Similar results are found by Haro et al. [9], Haro et al. [15], Haro et al. [16] who showed that mycorrhizal inoculation stimulated height growth of cowpea and that growth stimulation is more noticeable from the 35th day after sowing. Being the basic component of growth analysis that resulted from the work of de Blackman [12], the relative growth rate (RGR) of the plant or crop is defined at any instant in time (T) as the increase of the material present and is the only component of the growth analysis which does not require knowledge of the size of the assimilation system 
[11]. In this study, the height relative growth rate and collar diameter relative growth rate were used to assess the performance of mycorrhizal strains or the effects of mycorrhizal inoculation on plant growth. This made it possible to show that the plant growth variability observed in this study could be due to the difference in the AMF effectiveness in improving the mineral elements assimilation. As a result, Yac 2 mix appears to be more effective in improving cowpea growth. These results corroborate those of Haro et al. [17] who have shown the effectiveness of mycorrhizal symbiosis on improving the growth of Mucunapruriens. These authors also showed that this efficacy was linked to the mycorrhizal inoculum. Similar results were found by Haro et al. [18] on Zea mays. These results are confirmed by the phosphorus and nitrogen content of the aerial parts which are further improved by Yac 2 mix. Similar results were found by Haro et al. [6] on cowpea. Also, Ndonda et al. [19] have shown that mycorrhizal inoculation allows both increases in cassava yield, the availability of phosphorus formerly complexed by soil acid cations and the acceleration of the biosynthesis of the total carotenoid of yellow cassava.

The Yac 2 mix inoculum improves height growth (95.5\%), height relative growth rate $(525 \%)$, collar diameter (138\%), collar diameter relative growth rate (328.57\%), shoot biomass (396.3\%), root biomass by (205.66\%), total biomass by (320\%), total nitrogen of aerial parts $(92.39 \%)$ and total phosphorus of aerial parts (143.48\%) compared to control. These results corroborate those of Haro et al. [5], Haro et al. [20], Haro et al. [6], Haro et al. [7]. These authors have shown that cowpea growth and production are improved by mycorrhizal inoculation with native AMF.

\section{Conclusions}

In this study, it appears that the effect of inoculation is variable. Yac 2 mix is the most efficient of all the inocula used. This inoculum allows a considerable improvement in the production of cowpea biomass which can be used for the production of cowpea fodder. In addition to mycorrhizae, cowpeas also associate with soil bacteria (rhizobia). It would be interesting to extend this study by including rhizobial inoculations and the double mycorrhizal and rhizobial inoculations to assess the effect of these inoculations on cowpea biomass production. The results obtained are promising, but this study was carried out under controlled conditions and on a sterile substrate. It would be interesting to extend this study in non-sterile soil and even in situ.

\section{Acknowledgements}

This work benefited from the support of Laboratoire Mixte International (LMI) "Intensification écologique des sols cultivésen Afrique de l'Ouest" (IESOL).

\section{Conflicts of Interest}

The authors declare no conflicts of interest regarding the publication of this paper. 


\section{References}

[1] Kiema, A., Tontibomma, G. and Zampaligré, N. (2014) Transhumance et gestion des ressources naturelles au Sahel: contraintes et perspectives face aux mutations des systèmes de productions pastorals. Electronic Journal in Environmental Sciences, 14, 1-16. https://doi.org/10.4000/vertigo.15404

[2] Obulbiga, M.F., Bougouma, V. and Sanon, H.O. (2015) Improvement of Fodder Supply by the Dual-Use Cereal-Leguminous Crop Association in the Northern Sudanese Zone of Burkina Faso. International Journal of Biological and Chemical Science, 9, 1431-1439. https://doi.org/10.4314/ijbcs.v9i3.26

[3] Bado, B.V. (2002) Role of Legumes on the Fertility of Tropical Ferruginous Soils in the Guinean and Sudanese Areas of Burkina Faso. Laval University, Quebec.

[4] Pierre, S. (2012) In Vitro Evaluation of the Bioprotective Potential of Arbuscular Mycorrhizal Fungi against Bacterial Wilt in Tomato. Catholic University of Louvain, Belgium.

[5] Haro, H., Sanon, K.B., Blagna, F. and Fofana, B. (2016) Effect of Native Arbuscular Mycorrhiza Fungi Inocula on the Growth of Cowpea [Vigna unguiculata (L.) Walp.] in Three Differents Agro Ecological Zones in Burkina Faso. Journal of Applied Biosciences, 108, 10553-10560. https://doi.org/10.4314/jab.v108i1.8

[6] Haro, H., Sanon, K.B., Le Roux, C., Duponnois, R. and Traoré, A.S. (2017) Improvement of Cowpea Productivity by Rhizobial and Mycorrhizal Inoculation in Burkina Faso. Symbiosis, 74, 107-120. https://doi.org/10.1007/s13199-017-0478-3

[7] Haro, H., Sanon, K.B. and Traoré, A.S. (2016) Improvement of Cowpea Productivity by Rhizobial and Mycorrhizal Inoculation in Yakouta, Northern Burkina Faso. Science and technology: Natural Sciences and Agronomy, 2, 111-121.

[8] Haro, H. (2016) Optimization of Rhizobial and Mycorrhizal Symbioses to Improve the Cowpea [Vigna unguiculata (L.) Walp.] Productivity in Burkina Faso. (Ph. D.), Ouaga 1 University Professor Joseph Ki-Zerbo, Ouagadougou, Burkina Faso.

[9] Haro, H., Sanon, K.B., Diop, I., Kane, A., Dianda, M., Houngnandan, P., Neyra, M. and Traoré, A. (2012) Response to Mycorrhizal Inoculation of Four Varieties of Cowpea [Vigna unguiculata (L.) Walp.] Cultivated in Burkina Faso and Senegal. International Journal of Biological and Chemical Science, 6, 2097-2112. https://doi.org/10.4314/ijbcs.v6i5.18

[10] Hoffmann, W.A. and Poorter, H. (2002) Avoiding Bias in Calculations of Relative Growth Rate. Annals of Botany, 90, 37-42. https://doi.org/10.1093/aob/mcf140

[11] Beadle, C.L. (1985) Plant Growth Analysis. In: Coombs, J., Hall, D.O., Long, S.P. and Scurlock, J.M.O., Eds., Techniques in Bioproductivity and Photosynthesis, Pergamon, Oxford, 20-25. https://doi.org/10.1016/B978-0-08-031999-5.50012-1

[12] Blackman, V.H. (1919) The Compound Interest Law and Plant Growth. Annals of Botany, 33, 353-360. https://doi.org/10.1093/oxfordjournals.aob.a089727

[13] Phillips, J.M. and Hayman, D.S. (1970) Improved Procedures for Clearing Roots and Staining Parasitic and Vesicular-Arbuscular Mycorrhizal Fungi for Rapid Assessment of Infection. Transactions of the British Mycological Society, 55, 158-161. https://doi.org/10.1016/S0007-1536(70)80110-3

[14] Trouvelot, A., Kough, J.L., Gianinazzi-Pearson, V. and Gianinazzi, S. (1986) Rate Measurement of VA Mycorrhization of a Root System. Search for Estimation Methods with Functional Significance. Mycorrhizae, Physiology and Genetics, 217-221.

[15] Haro, H., Sanon, K.B., Diop, I., Kane, A., Dianda, M., Houngnandan, P., Neyra, M. and Traoré, A.S. (2011) Sensitivity to Mycorrhizal Inoculation of Four Varieties of 
Cowpea Cultivated in Burkina Faso and Senegal. Paper Presented at the Restoration, Conservation and Promotion of Plant Biodiversity, Africa Dakar (Sénégal), 11 au 15 avril 2011.

[16] Haro, H., Sanon, K.B. and Traoré, A.S. (2012) Response to Mycorrhizal Inoculation of Two Varieties of Cowpea [ Vigna unguiculata (L.) Walp.] Grown in Burkina Faso. Paper Presented at the Biotechnologies Facing the Challenges of Sustainable Development in West and Central African States, Ouagadougou (Burkina Faso), 6-9, November 2012.

[17] Haro, H., Semdé, K., Bahadio, K. and Sanon, B.K. (2020) Effect of Mycorrhizal Inoculation with Arbuscular Mycorrhizal Fungi Strains on Mucuna pruriens (L.) DC Growth under Controlled Condition. International Journal of Biological and Chemical Science, 14, 1065-1073. https://doi.org/10.4314/ijbcs.v14i3.32

[18] Haro, H., Semdé, K. and Bahadio, K. (2020) Native Arbuscular Mycorrhizal Inoculation of Corn (Zea mays L.) Cultivated in Burkina Faso. Journal of Applied Biosciences, 149, 15291-15296.

[19] Ndonda, A., Mahungu, N., Moango, A. and Yandju, M.C. (2019) Effect of Arbuscular Mycorrhizal Fungi (AMF) on Total Phosphorus in Tropical Forest Fallow Soils and Their Involvement in Carotenoid Biosynthesis in Cassava. Journal of Applied Biosciences, 135, 13750-13764.

[20] Haro, H., Sanon, K.B., Krasova-Wade, T., Kane, A., N’Doye, I. and Traoré, A.S. (2015) Response to Double Mycorrhizal and Rhizobial Inoculation of Cowpea (Variety, KVX396-4-5-2D) Cultivated in Burkina Faso. International Journal of Biological and Chemical Science, 9, 1485-1493. https://doi.org/10.4314/ijbcs.v9i3.31 